\title{
Humoral Immune Responses to T Cell Tropic Retrovirus Simian T Lymphotropic Virus Type III in Monkeys with Experimentally Induced Acquired Immune Deficiency-like Syndrome
}

\author{
Mari Kannagi, Masaya Kiyotaki, Ronald C. Desrosiers, Keith A. Reimann, Norval W. King, \\ Linda M. Waldron, and Norman L. Letvin \\ Harvard Medical School, New England Regional Primate Research Center, Southborough, Massachusetts 01772
}

\begin{abstract}
The $\mathbf{T}$ cell tropic retrovirus of macaque monkeys simian $\mathbf{T}$ lymphotropic virus type III (STLV-III) has morphologic, growth, and antigenic properties indicating that it is related to human $T$ cell lymphotropic virus type III/lymphadenopathy-associated virus (HTLV-III/LAV), the etiologic agent of the acquired immune deficiency syndrome (AIDS) of humans. STLV-III has recently been shown to induce an AIDS-like disease in macaque monkeys. In this study the humoral immune responses of six experimentally infected monkeys have been characterized to determine whether certain parameters of the antibody response to the virus might be predictive of the clinical outcome of this infection. Two distinct patterns of antibody responses were found. Four animals that died within $160 \mathrm{~d}$ of inoculation developed low titer anti-STLV-III antibody responses that recognized only the viral envelope protein, and progressive declines in total plasma IgG levels and absolute peripheral blood T4 lymphocyte numbers. The two animals that lived longer (one died at $352 \mathrm{~d}$, the other remains alive at $\mathbf{4 3 0} \mathrm{d}$ ) developed high titer anti-STLVIII antibody responses that recognized both viral envelope and core proteins, increases in total plasma IgG, and a later decrease in number of peripheral blood T4 lymphocytes. Interestingly, the single animal that has remained clinically healthy after infection was the only one to develop detectable STLV-III neutralizing antibodies.
\end{abstract}

\section{Introduction}

Considerable progress has been made in characterizing the antibody responses of individuals infected with human $\mathrm{T}$ cell lymphotropic virus type III/lymphadenopathy-associated virus (HTLV-III/LAV), ${ }^{1}$ the human acquired immune deficiency syndrome (AIDS) virus. The major HTLV-III/LAV-encoded proteins recognized by sera of infected individuals $(1,2)$ and the weak in vitro neutralizing activity of these sera $(3,4)$ have been defined. However, little information is available that correlates

Received for publication 3 April 1986 and in revised form 9 June 1986.

1. Abbreviations used in this paper: AIDS, acquired immune deficiency syndrome; ELISA, enzyme-linked immunosorbent assay; gp, glycoprotein; HTLV-III/LAV, human T cell lymphotropic virus type III/lymphadenopathy-associated virus; IL-2, interleukin 2; Mm, Macaca mulatta; $\mathrm{RT}$, reverse transcriptase; STLV-III, simian T lymphotropic virus type III.

J. Clin. Invest.

(c) The American Society for Clinical Investigation, Inc. $0021-9738 / 86 / 11 / 1229 / 08 \quad \$ 1.00$

Volume 78, November 1986, 1229-1236 the nature of these antibody responses with clinical disease course in infected individuals. Given the large number of individuals infected with HTLV-III/LAV, it is important to determine whether specific characteristics of the humoral immune response to the virus might predict the clinical outcome of those infections.

Elucidation of such predictive parameters would be most readily accomplished in an animal model of AIDS in which experimentally infected animals could be regularly and intensively studied. The only animal species shown to be infectable with HTLV-III/LAV is the chimpanzee. However, chimpanzees have developed no signs of disease following infection with the human virus (5-8). Thus, while the chimpanzee will be important for the development of an AIDS vaccine, it is not an ideal experimental animal in which to study the viral pathogenesis of AIDS.

A T cell tropic retrovirus with striking similarities to HTLVIII/LAV was recently isolated from macaque monkeys at the New England Regional Primate Research Center (9). We have called this virus simian T lymphotropic virus type III (STLVIII) of macaques. Like HTLV-III/LAV, STLV-III can be isolated from $\mathrm{T}$ lymphocytes and grows preferentially in $\mathrm{T} 4+$ rather than T8+ lymphocytes (10). By electron microscopy, mature particles have a cylindrical nucleoid and the virus buds in a fashion typical of type C retroviruses (9). Furthermore, STLV-III- and HTLVIII/LAV-encoded proteins are serologically cross-reactive (11). In preliminary studies with this agent, juvenile rhesus monkeys died with a wasting syndrome, opportunistic infections, a primary retroviral encephalitis, and immunologic abnormalities following STLV-III inoculation (12). Thus, STLV-III induces an AIDS-like disease in rhesus monkeys.

In this study we have characterized the humoral immune response of rhesus monkeys experimentally infected with STLVIII. This was done to determine whether specific parameters of the antibody response to STLV-III might be predictive of the clinical outcome of this infection. We show that the pattern of the anti-STLV-III antibody response of infected monkeys does correlate with clinical disease course. These patterns of virusspecific antibody response also correlated with changes in levels of both the total plasma immunoglobulin $\mathrm{G}$ (IgG) and the absolute peripheral blood T4 cells.

\section{Methods}

Animal inoculations. Six juvenile rhesus monkeys were experimentally infected as previously described with STLV-III that was isolated from a rhesus monkey that died with a lymphoma (12). Each animal was inoculated with $1.7 \mathrm{ml}$ of the same cell-free supernatant of a STLV-IIIinfected interleukin 2 (IL-2)-dependent human peripheral blood lymphocyte culture containing $146,000 \mathrm{cpm} / \mathrm{ml}$ reverse transcriptase (RT) activity.

Indirect immunofluorescence. An indirect immunofluorescence staining method was used for detection of plasma antibodies against 
STLV-III. STLV-III-infected and uninfected H9 cells were used as antigen-expressing and negative control cells. Plasma from animals was inactivated at $56^{\circ} \mathrm{C}$ for $60 \mathrm{~min}$. Smears of infected and uninfected $\mathrm{H} 9$ cells were fixed with acetone at room temperature for $7 \mathrm{~min}$, dried, then incubated with plasma at $37^{\circ} \mathrm{C}$ for $45 \mathrm{~min}$. After three washes with phosphate-buffered saline (PBS), these smears were incubated with fluorescein-conjugated goat anti-serum to human polyvalent immunoglobulins (Meloy Laboratories Inc., Springfield, VA) at $37^{\circ} \mathrm{C}$ for $45 \mathrm{~min}$, washed three times with PBS, and examined under a fluorescence microscope.

Enzyme-linked immunosorbent assay (ELISA). STLV-III was harvested from producing Hut-78 cells $\sim 72 \mathrm{~h}$ after a 1 to 3 split. Cells were removed by centrifugation at $500 \mathrm{~g}$ for $15 \mathrm{~min}$ and the supernatant was filtered through disposable $0.2-\mu \mathrm{m}$ Nalgene filters to remove residual cells and debris. Virus was then pelleted at $35,000 \mathrm{~g}$ for $180 \mathrm{~min}$ in a Beckman type 19 rotor. The supernatant was removed and the virus was resuspended overnight in TNE buffer $(20 \mathrm{mM}$ Tris $\mathrm{HCl}, 100 \mathrm{mM} \mathrm{NaCl}$, $1 \mathrm{mM}$ EDTA, $\mathrm{pH} 7.5$ ) at $4^{\circ} \mathrm{C}$. After fractionation by Sepharose 4B column chromatography, purified virus contained in the void volume was pooled and pelleted again by centrifugation (13). Purified virus was resuspended in $100 \mu \mathrm{l}$ of calcium-magnesium-free PBS containing $0.5 \%$ Triton X-100 and $0.6 \mathrm{M} \mathrm{KCl}$ for each 1 liter of culture. Lysed virus was stored at $-70^{\circ} \mathrm{C}$ before coating wells of ELISA plates with viral antigen. Virus was diluted 1:1,000 with calcium-magnesium-free PBS and 100 $\mu \mathrm{l}$ of this was added to each well of Nunc immunoplates. After incubation at room temperature overnight, the plates were rinsed with water and unbound sites were blocked by $10 \mathrm{~min}$ incubation with $0.3 \%$ bovine serum albumin. The plates were rinsed again with water and stored at $4^{\circ} \mathrm{C}$ in sealed bags before use.

Plasma diluted with $10 \%$ heat-inactivated goat serum, and $0.05 \%$ Tween 20 in PBS was incubated in antigen-coated wells for $1 \mathrm{~h}$ at room temperature; wells were then rinsed three times with $0.05 \%$ Tween 20 in PBS. $100 \mu$ l of alkaline phosphatase-conjugated goat antibody to human IgG was added to each well and incubated for $1 \mathrm{~h}$ at room temperature. The wells were rinsed three times again and $p$-nitrophenyl phosphate substrate, prepared as described by the manufacturer (Kirkegaard and Perry Laboratories, Inc., Gaithersburg, MD), was added. After 30 min, sodium hydroxide was added to a concentration of $0.6 \mathrm{M}$ and the absorbance recorded at $410 \mathrm{~nm}$ with a Dynatech 600 microplate reader. Plasma samples were diluted 1:20 followed by serial fourfold dilutions for testing. The antibody titer determined by ELISA was defined as that dilution of plasma that resulted in an optical density reading of $<0.1$.

Radioimmunoprecipitation. H9 or STLV-III-infected H9 cells were radiolabeled with $\left[{ }^{35} \mathrm{~S}\right]$ methionine $(150 \mu \mathrm{Ci} / \mathrm{ml}$, New England Nuclear, Boston, MA) for $4 \mathrm{~h}$. The labeled cells were resuspended in lysis buffer (1\% Triton X-100, 0.05 M Tris-HCl buffer, pH 7.2, 0.15 M NaCl, $1 \mathrm{mM}$ ethylenediaminetetraacetic acid, $1 \%$ aprotinin, and $1 \mathrm{mM}$ phenylmethylsulfonyl fluoride) and cleared by centrifugation for $1 \mathrm{~h}$ at 100,000 g. Macaque plasma, 10-138 $\mu \mathrm{l}$ (the sample sizes being varied to normalize for total IgG concentration in the plasma of each animal), were incubated with protein A-sepharose CL-4B (Sigma Chemical Co., St. Louis, MO) and, after washing, antibody-coated beads were incubated with the cell lysate. After further washing, immunoprecipitates were eluted from the protein A-sepharose beads with sample buffer (5\% 2-mercaptoethanol, $2 \%$ sodium dodecyl sulfate (SDS), $0.08 \mathrm{M}$ Tris-HCl, pH 6.8, $10 \%$ glycerol, and $0.001 \%$ bromophenol blue) by boiling at $100^{\circ} \mathrm{C}$ for $3 \mathrm{~min}$. Samples were analyzed by electrophoresis in 10\% SDS-polyacrylamide gels with a 3\% stacking gel according to the discontinuous buffer system of Laemmli (14).

Neutralization. Cell-free STLV-III containing culture supernatants were aliquoted and stored in liquid nitrogen for subsequent use in the neutralization studies. Macaque plasma was heat-inactivated and 0.3 $\mathrm{ml}$, diluted 1:2 with PBS, was mixed with $0.3 \mathrm{ml}$ of various dilutions of supernatant containing virus and incubated at $37^{\circ} \mathrm{C}$ for $1 \mathrm{~h}$. This mixture was incubated with $2 \times 10^{6}$ human phytohemagglutinin-stimulated peripheral blood lymphocytes (PBL) at $37^{\circ} \mathrm{C}$ for $2 \mathrm{~h}$. Cells were then washed three times with PBS, resuspended in $2.5 \mathrm{ml}$ RPMI 1640 medium con- taining $10 \%$ fetal calf serum and $0.1 \%$ recombinant interleukin 2 (IL-2) (kindly provided by E. I. DuPont Nemours, Inc., Wilmington, DE). They were cultured in 24-well plates (NUNC, Boston, MA) at $37^{\circ} \mathrm{C}$ in humidified air with $5 \% \mathrm{CO}_{2}$. 1-ml aliquots of culture supernatants were harvested every 3 to $4 \mathrm{~d}$ and medium was changed at the same time. Culture supernatants were filtered and stored at $-70^{\circ} \mathrm{C}$. RT activities of culture supernatants were measured as previously described (10).

Radioimmunoassay for total plasma IgG quantitation. IgG was purified from normal rhesus monkey serum by ammonium sulfate precipitation and gel filtration through Sephacryl S-300 (Pharmacia Fine Chemicals, Piscataway, NJ). Radioiodination of monkey IgG was performed using the method previously described (15). Monoclonal antihuman IgG antibody (kindly provided by Victor Raso, Dana-Farber Cancer Institute, Boston, MA) was adsorbed for $2 \mathrm{~h}$ at $4^{\circ} \mathrm{C}$ onto flexible polyvinyl microtiter plates (Becton-Dickinson \& Co., Oxnard, CA). Wells were then incubated with $1 \%$ bovine serum albumin in PBS for $1 \mathrm{~h}$ to block nonspecific binding sites on the plastic and washed three times with PBS. Equal volumes of appropriately diluted test plasma from inoculated monkeys and ${ }^{125}$ I-labeled monkey IgG were incubated in the wells overnight. The wells were washed three times with PBS, cut from the plate, and counted on an automated gamma counter. Test plasma values were interpolated from a standard curve.

Quantitation of circulating T4+ and T8+ lymphocytes. PBL were isolated from blood samples by Ficoll/sodium diatrizoate density gradient centrifugation, washed in Hanks' balanced salt solution (HBSS), and incubated in aliquots of $1 \times 10^{6}$ cells for $20 \mathrm{~min}$ at $4^{\circ} \mathrm{C}$ with monoclonal anti-T4 and anti-T8 antibodies (kindly provided by Stuart Schlossman, Dana-Farber Cancer Institute, Boston, MA). The cells were then washed in HBSS and incubated in fluorescein isothiocyanate-conjugated goat anti-mouse Ig (Tago Inc., Burlingame, CA) for $20 \mathrm{~min}$ at $4^{\circ} \mathrm{C}$. After washing each sample in PBS and fixing with a $1 \%$ formalin solution, cytofluorographic analysis of cell populations was performed on a fluorescence-activated cell sorter (FACS-1; Becton-Dickinson \& Co., Mountainview, CA). The peripheral blood T4 and T8 counts were determined by the following calculation: peripheral blood white cell count $X$ percent lymphocytes $X$ percent cells stained by that monoclonal antibody.

\section{Results}

Clinical course of disease. Six juvenile rhesus monkeys were experimentally infected with STLV-III (Table I) (12). STLV-III was isolated from their plasma at 2 wk and PBL at 17 wk after inoculation (12). Four died between 127 and $160 \mathrm{~d}$ after inoculation (Macaca mulatta [Mm] 91-84, Mm 99-84, Mm 101-84, Mm 106-83). These four monkeys had diarrhea by 1 mo after infection and three (Mm 91-84, Mm 101-84, and Mm 106-83) lost 13,34 , and $60 \%$ of their body weight during the study. At necropsy, the thymuses of the four monkeys were atrophic. Three (Mm 91-84, Mm 99-84, and Mm 101-84) had evidence of extensive necrotizing adenovirus infections that involved pancreas, lung, and biliary tract. All four died with a primary retroviral encephalitis. Perivascular infiltrates of large, foamy macrophages with occasional multinucleated giant cells were scattered throughout the white and grey matter of the brain (Fig. $1 \mathrm{~A}$ ). Electron microscopic examination of these lesions revealed STLV-III particles in the macrophages (Fig. $1 B$ ).

A fifth animal (Mm 74-84) developed transient lymphadenopathy $8 \mathrm{mo}$ after inoculation and died $4 \mathrm{mo}$ later having lost $24 \%$ of its body weight. It was noted at necropsy to have thymic atrophy and cryptosporidiosis. The final monkey (Mm 127-83) developed transient lymphadenopathy $1 \mathrm{yr}$ after inoculation and has otherwise remained healthy.

Anti-STLV-III antibody responses. Plasma from blood samples drawn at regular intervals from the six monkeys was 
Table I. Clinical Histories of Six

STLV-III-infected Rhesus Monkeys

\begin{tabular}{|c|c|c|c|}
\hline Animal & $\begin{array}{l}\text { Lymphadenopathy } \\
\text { syndrome }\end{array}$ & $\begin{array}{l}\text { Day } \\
\text { postinoculation } \\
\text { of death }\end{array}$ & Clinical features \\
\hline Mm 91-84 & No & 127 & $\begin{array}{l}\text { Weight loss; thymic } \\
\text { atrophy; adenovirus } \\
\text { infection of pancreas; } \\
\text { encephalitis }\end{array}$ \\
\hline Mm 101-84 & No & 142 & $\begin{array}{l}\text { Weight loss; thymic } \\
\text { atrophy; adenovirus } \\
\text { infection of pancreas, } \\
\text { biliary tract, and } \\
\text { lung; encephalitis }\end{array}$ \\
\hline Mm 106-83 & No & 148 & $\begin{array}{l}\text { Weight loss; thymic } \\
\text { atrophy; encephalitis }\end{array}$ \\
\hline Mm 99-84 & No & 160 & $\begin{array}{l}\text { Thymic atrophy; } \\
\text { adenovirus infection } \\
\text { of pancreas; } \\
\text { encephalitis }\end{array}$ \\
\hline Mm 74-84 & Yes & 352 & $\begin{array}{l}\text { Weight loss; thymic } \\
\text { atrophy; } \\
\text { cryptosporidiosis }\end{array}$ \\
\hline Mm 127-83 & Yes & - & Healthy \\
\hline
\end{tabular}

assessed for anti-STLV-III antibody titer by indirect immunofluorescence. As shown in Fig. 2, two patterns of anti-STLVIII antibody responses were seen. The four animals that died within $160 \mathrm{~d}$ of inoculation (Mm 91-84, Mm 99-84, Mm 10184, and Mm 106-83) developed peak antibody titers of only 1 : 16-1:64 by $17 \mathrm{~d}$ after experimental infection. The titers fell to $1: 4$ or below in the weeks before their deaths. The two monkeys that did not die within $160 \mathrm{~d}$ (Mm 74-84 and Mm 127-83) developed peak anti-STLV-III antibody titers of 1:4,000-1:16,000 by $122 \mathrm{~d}$ after inoculation. Their high antibody titers persisted.

The titer of anti-STLV-III IgG antibody in the six inoculated monkeys was also measured using an ELISA procedure. Similar to the indirect immunofluorescence measurements, $\mathrm{Mm}$ 74-84 and $\mathrm{Mm}$ 127-83 developed high titer antibodies that persisted (Table II). IgG antibody appeared earlier in the macaque that is still alive (Mm 127-83) then in the macaque that died at 352 days (Mm 74-84). The four animals that died 127-160 d postinoculation developed little or no antibody detectable by ELISA. Thus, the titration of antibodies by ELISA agreed quite well with the indirect immunofluorescence measurements.

Viral proteins recognized by monkey antibodies. Plasma samples from the six inoculated animals were analyzed using radioimmunoprecipitation of labeled proteins from infected cells followed by gel electrophoresis to assess the presence of antibodies that recognize the presumed major virus-encoded proteins of STLV-III. As shown in Fig. 3, the four monkeys that died within

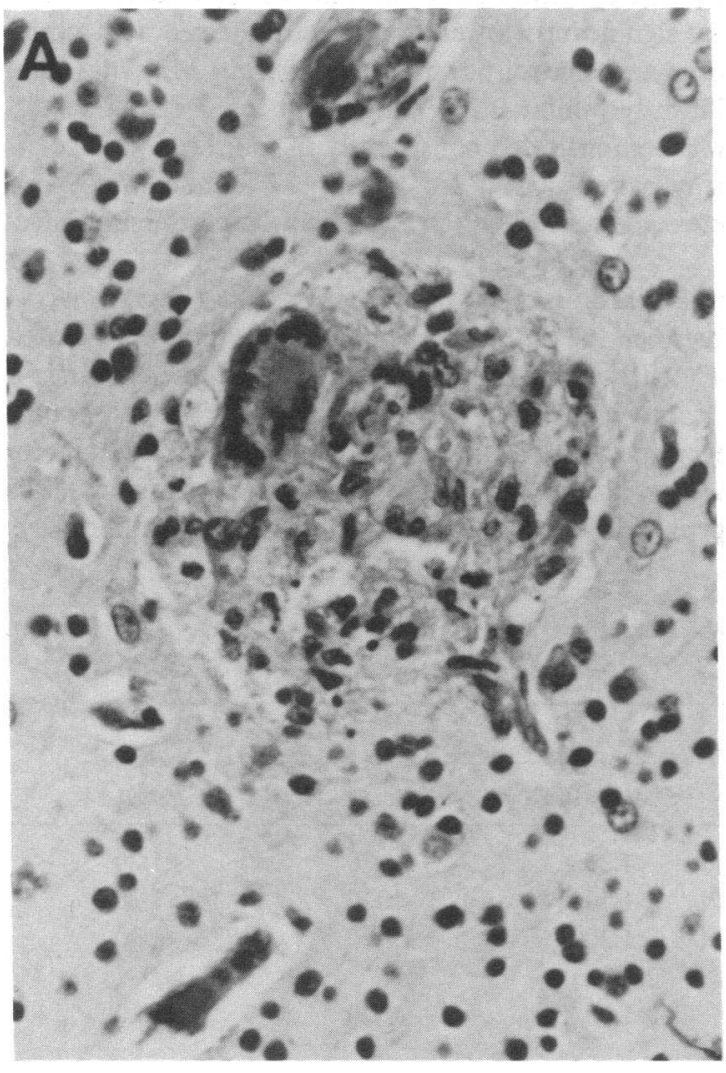

Figure 1. (A) Photomicrograph of a portion of the cerebral cortex in which there are two (one large and one small) perivascular infiltrates of macrophages. The larger infiltrate also contains a multinucleated, syncytial giant cell. The vessels in each lesion are sectioned tangentially (hematoxylin and eosin, $\times 350$ ). (B) Electron micrograph of a

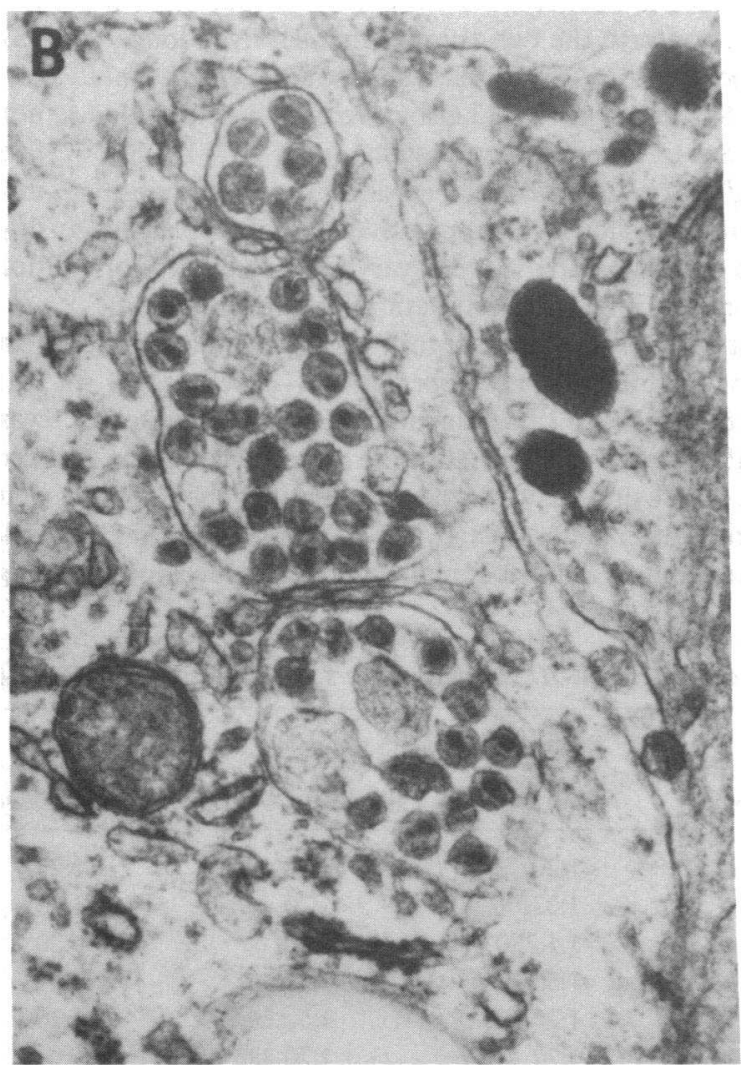

portion of the cytoplasm of a macrophage from a perivascular infiltrate in the brain. There are many STLV-III retrovirus particles contained within membrane-bound vacuoles presumed to be phagosomes. Note the cylindrical-shaped nucleoids in several of the particles. No budding particles were found in these cells. 


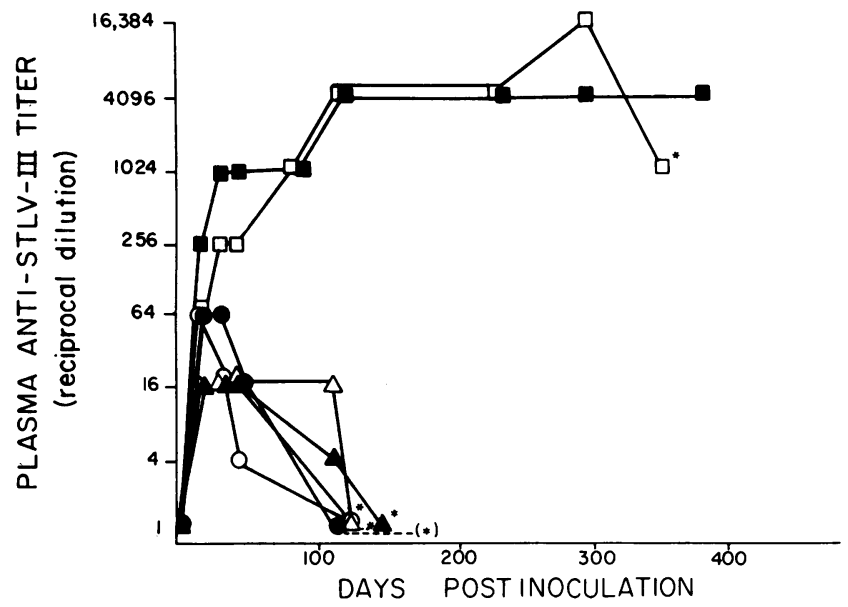

Figure 2. Plasma anti-STLV-III titers of rhesus monkeys determined by indirect immunofluorescence after experimental infection with STLV-III. * Denotes time of death (0, Mm 91-84; •, Mm 99-84; $\Delta$, Mm 101-84; ^, Mm 106-84; 口, Mm 74-84; a, Mm 127-83).

$160 \mathrm{~d}$ of infection (Mm 91-84, Mm 99-84, Mm 101-84, and Mm 106-83) developed weak transient antibody responses only to the $160 / 120-\mathrm{kD}$ viral envelope glycoprotein (gp). These weak antibody responses did not simply reflect low plasma IgG levels, but in fact were due to decreased specific antibody responses since the amount of plasma used for each immunoprecipitation was varied in order to normalize the quantity of total IgG in each sample. In contrast, the two animals that survived longer (Mm 74-84 and Mm 127-83) developed strong antibody responses to gp 160/120. Mm 127-83 also developed a detectable antibody response to the viral core proteins (p55, p27) by day 32 (Fig. 3), while Mm 74-84 developed an anti-core response by day 235 (data not shown). Comparative studies of plasma from these two animals, done without varying the quantity of plasma used for each immunoprecipitation, demonstrated differences in their antibody responses. Mm 74-84, which died $\sim 1$ yr after experimental infection, developed an anti-envelope IgG antibody response by day 32 postinoculation, which persisted until death. Antibodies to p55 and p27 were not detected in the plasma of Mm 74-84 until day 235 postinoculation; these antibodies were no longer detectable by day 329 postinfection. Mm 127-83, the monkey that has remained healthy, developed earlier and more persistent antibodies to the envelope and core viral antigens. Antibody to gp 160/120 was detected by day 17 postinfection and has persisted. Antibodies to p55 and p27 appeared by day 32 , were still detectable on day 329 , but were no longer present on day 367 postinoculation. No significant decrease in indirect immunofluorescence anti-STLV-III antibody titer or total plasma IgG levels was noted in plasma samples from Mm 127-83 during that time interval. The gp 160/120, p55, and p27 were the only viral proteins that could be detected using plasma samples from these animals under these experimental conditions.

Plasma neutralization studies. We assessed the STLV-III neutralizing activity of plasma samples from the two monkeys that developed high titer antibodies specific for STLV-III (Mm 127-83 and Mm 74-84) (Table III). The paired plasma samples used in this study showed the same antibody titer against STLVIII ( $1: 4^{6}$ by indirect immunofluorescence). The virus isolate utilized for the neutralizing assay was the same as that used to infect the six monkeys. A preliminary titration of the virus-containing supernatant showed that the minimum concentration of supernatant necessary for a productive infection of the target cells detectable by RT assay was between a dilution of $1: 32$ and 1:64. When the virus-containing supernatant was added to the assay at a greater concentration than a 1:10 dilution, neither plasma affected the generation of RT by the target lymphocytes. If the virus containing supernatant was diluted $>1: 36$, its addition to the cultures did not result in reproducible infections. Viral replication in the cells infected with the mixture of virus-containing supernatant diluted 1:16 or 1:36 and plasma from $\mathrm{Mm}$ 127-83 was significantly lower than in cells infected with a mixture of virus and control plasma. Plasma from Mm 74-84 did not significantly inhibit RT generation in this assay. This difference was demonstrated consistently in four separate experiments using paired plasma from Mm 127-84 and Mm 74-84 drawn between days 123 and 225 following experimental infection.

Total plasma IgG levels. While these results suggested a correlation between the nature of the antibody response generated by the STLV-III-infected monkeys and their clinical course, it was not clear to what extent these patterns in antibody responses were antigen specific. To address this issue, total IgG levels were determined on plasma samples taken at various time intervals following experimental STLV-III infection of the monkeys (Fig. 4).

Table II. Plasma Anti-STLV-III Antibody Titers As Determined by ELISA

\begin{tabular}{|c|c|c|c|c|c|c|}
\hline \multirow{2}{*}{$\begin{array}{l}\text { Days } \\
\text { postinoculation }\end{array}$} & \multicolumn{6}{|c|}{ Experimentally infected monkeys } \\
\hline & Mm 127-83 & Mm 74-84 & Mm 106-84 & Mm 101-84 & Mm 99-84 & Mm 91-84 \\
\hline 15 & $<1: 20$ & $<1: 20$ & $<1: 20$ & $<1: 20$ & $<1: 20$ & $<1: 20$ \\
\hline 30 & $1: 320^{*}$ & $<1: 20$ & $<1: 20$ & $<1: 20$ & $<1: 20$ & $<1: 20$ \\
\hline 45 & $1: 1,280$ & $1: 80$ & $<1: 20$ & $<1: 20$ & $<1: 20$ & $<1: 20$ \\
\hline 85 & $1: 5,120$ & $1: 1,280$ & $\mathbf{N T} \ddagger$ & NT & NT & $\mathbf{N T}$ \\
\hline 120 & $1: 20,480$ & $1: 5,120$ & $<1: 20$ & $<1: 20$ & $<1: 20$ & $<1: 20$ \\
\hline 240 & $1: 20,480$ & $1: 20,480$ & & & & \\
\hline 300 & $1: 20,480$ & $1: 20,480$ & & & & \\
\hline 330 & $\mathbf{N T}$ & $1: 20,480$ & & & & \\
\hline 350 & $1: 20,480$ & & & & & \\
\hline
\end{tabular}

* Dilution of plasma resulting in optical density reading of $<0.1 . \ddagger N T$, not tested. 


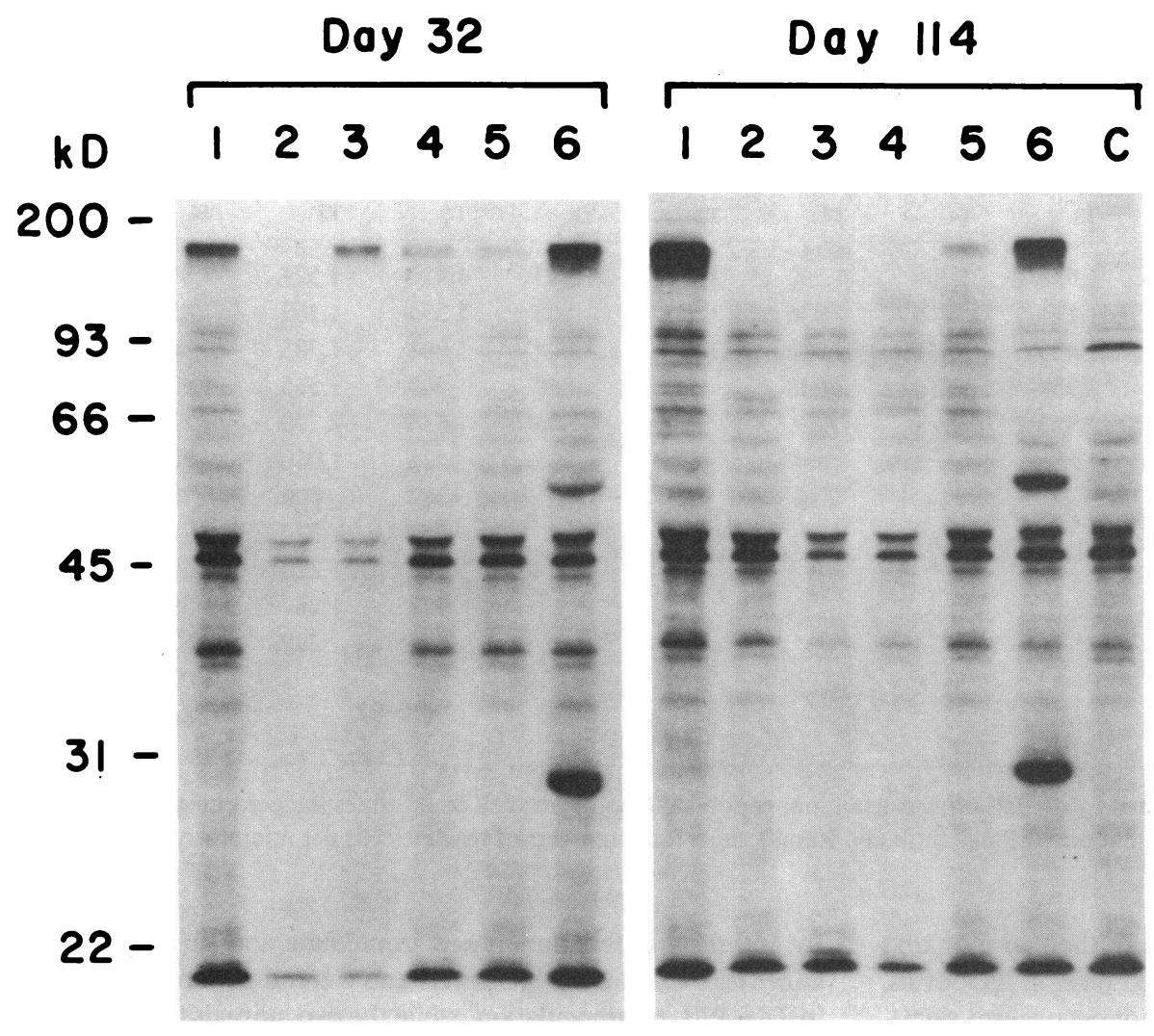

Figure 3. Detection of antibody responses to STLV-III using radioimmunoprecipitation and gel electrophoresis.

$\left[{ }^{35}\right.$ S]Methionine radiolabeled uninfected $\mathrm{H} 9$ (lane $C$ ) or H9-STLV-III-infected cell lysates were reacted with $10-138 \mu \mathrm{l}$ of macaque plasma bound to protein A-Sepharose CL-4B. (Sample sizes were varied to normalize for total IgG concentration in the plasma of each animal.) Lane $1, \mathrm{Mm} \mathrm{74-84}$ lane 2, Mm 91-84; lane 3, Mm 99-84; lane 4, Mm 101-84; lane 5, Mm 106-83; lane 6, Mm 127-83; these samples were all reacted with H9-STLV-III-infected lysates. Lane $C$, $\mathrm{Mm}$ 127-83 plasma was reacted with an $\mathrm{H} 9$ uninfected cell lysate. The immunoprecipitates were eluted and analyzed in 10\% SDS polyacrylamide gel.
The two animals surviving longer than $160 \mathrm{~d}(\mathrm{Mm}$ 74-84 and $\mathrm{Mm} \mathrm{127-83)}$ showed significant increases in total plasma IgG after STLV-III infection. This increase has been maintained

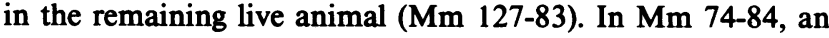
increased plasma IgG level was evident at least $250 \mathrm{~d}$ postinoculation, but this had markedly declined by the time of its death. All four animals that died by $160 \mathrm{~d}$ postinfection showed significant, progressive decreases in total plasma IgG levels after virus inoculation. No significant change in total plasma protein was associated with the decreases in total plasma IgG in the animals (data not shown). Thus, the changes in total IgG in the plasma of the monkeys did not reflect merely gross changes in plasma protein concentrations.

Table III. Neutralization of In Vitro STLV-III Infection by Plasma of STLV-III-infected Rhesus Monkeys

\begin{tabular}{lrlrr}
\hline & & \multicolumn{3}{l}{ Virus dilution } \\
\cline { 3 - 5 } Plasma source* & $\begin{array}{c}\text { Days of } \\
\text { culture }\end{array}$ & $1: 10$ & $1: 16$ & \multicolumn{1}{c}{$1: 36$} \\
\hline Mm 74-84 & 7 & $36,756 \ddagger$ & 19,003 & 2,215 \\
& 11 & 31,680 & 18,554 & 15,005 \\
Mm 127-83 & 7 & 44,490 & 3,402 & 304 \\
& 11 & 41,558 & 6,235 & 232 \\
Uninfected control & 7 & 44,791 & 23,232 & 4,711 \\
monkey & 11 & 37,972 & 22,078 & 16,364 \\
& & & & \\
\end{tabular}

* Plasmas from experimentally infected rhesus monkeys both showed antibody titers against STLV-III of 1:46 by indirect immunofluorescence.

$\ddagger$ cpm RT activity.
Circulating T4+ lymphocytes. Finally, we sought to determine if these patterns of clinical disease course and humoral immune status correlated with alterations in circulating T4+ lymphocytes in the STLV-III-infected animals (Table IV). The number of T4+ PBL decreased soon after experimental inoculation with STLV-III in the four monkeys that died rapidly and whose total plasma IgG levels decreased postinfection. While some variability was noted in their numbers of circulating T4+ lymphocytes, three of the four (Mm 91-84, Mm 101-84, and Mm 106-83) demonstrated decreases in T4+ PBL to below the normal $1,000 / \mathrm{mm}^{3}(12,16)$ by 3 wk after STLV-III inoculation. The fourth monkey (Mm 99-84) demonstrated a decrease in T4+ PBL by 12 wk postinfection. Immediately before death the

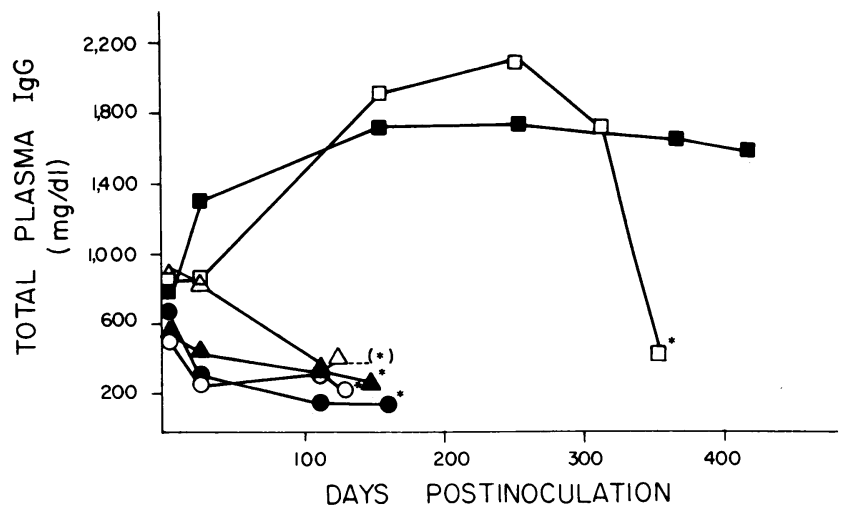

Figure 4. Total plasma IgG levels determined by radioimmunoassay after experimental infection of rhesus monkeys with STLV-III. * Denotes time of death (o, Mm 91-84; •, Mm 99-84; $\Delta$, Mm 101-84; $\Delta$, Mm 106-84; 口, Mm 74-84; 1 , Mm 127-83). 
Table IV. Changes in T4+ and T8+ Circulating Lymphocytes in Rhesus Monkeys after Inoculation with STLV-III

\begin{tabular}{|c|c|c|c|c|c|c|c|c|c|c|c|c|}
\hline \multirow{3}{*}{$\begin{array}{l}\text { Weeks } \\
\text { postinoculation }\end{array}$} & \multicolumn{12}{|c|}{ Experimentally infected monkeys } \\
\hline & \multicolumn{2}{|c|}{ Mm 91-84 } & \multicolumn{2}{|c|}{ Mm 101-84 } & \multicolumn{2}{|c|}{ Mm 106-83 } & \multicolumn{2}{|c|}{ Mm 99-84 } & \multicolumn{2}{|c|}{ Mm 74-84 } & \multicolumn{2}{|c|}{ Mm 127-83 } \\
\hline & $\mathrm{T}^{*}$ & T8 & $\mathrm{T} 4$ & T8 & $\mathrm{T} 4$ & T8 & T4 & $\mathrm{T} 8$ & $\mathrm{~T} 4$ & $\mathrm{~T} 8$ & $\mathrm{~T} 4$ & $\mathrm{~T} 8$ \\
\hline Pre- & 1,462 & 1,174 & 1,718 & 1,938 & 1,308 & 1,290 & 1,245 & 903 & 1,420 & 1,521 & 1,873 & 887 \\
\hline 3 & 962 & 605 & 732 & 1,171 & 455 & 936 & 1,213 & 808 & 1,574 & 1,303 & 1,831 & 2,093 \\
\hline 6 & 598 & 933 & 1,526 & 1,425 & 1,461 & 2,002 & 1,231 & 1,204 & 1,091 & 1,785 & 1,803 & 1,803 \\
\hline 12 & 1,089 & 1,053 & 824 & 1,957 & 840 & 2,058 & 516 & 860 & 909 & 1,515 & 1,439 & 1,738 \\
\hline 17 & & & 1,697 & 522 & & & 720 & 806 & 1,656 & 2,230 & 1,778 & 938 \\
\hline 20 & & & & & & & 672 & 806 & 525 & 1,050 & 804 & 731 \\
\hline 25 & & & & & & & & & 382 & 706 & 998 & 406 \\
\hline 28 & & & & & & & & & 553 & 322 & 714 & 272 \\
\hline 34 & & & & & & & & & 1,008 & 1,220 & 682 & 502 \\
\hline 39 & & & & & & & & & 927 & 1,287 & 1,698 & 1,338 \\
\hline 45 & & & & & & & & & 354 & 299 & 629 & 210 \\
\hline 52 & & & & & & & & & & & 1,008 & 743 \\
\hline 68 & & & & & & & & & & & 864 & 1,404 \\
\hline
\end{tabular}

* The absolute T4+ or T8+ count was determined by the following calculation: peripheral blood white cell count times the percentage of lymphocytes times the percentage of cells reactive with that monoclonal antibody. Results show total numbers of reactive cells per microliter.

T4+ PBL increased in two of the animals. In the two monkeys that survived longer and developed elevated plasma IgG levels, a decline in the number of T4+ PBL did not occur until significantly later after STLV-III infection. This decrease in Mm 74$84 \mathrm{~T} 4+$ PBL occurred 20 wk postinoculation. The T4:T8 ratio was only noted to be reversed in Mm 127-83 $68 \mathrm{wk}$ after experimental infection.

\section{Discussion}

Current estimates suggest that in the United States alone there are between 1 and 2 million individuals infected with HTLVIII/LAV (17). The clinical outcome of this infection has proven to be quite variable. Some infected individuals manifest no apparent disease or only transient lymphadenopathy, while others develop a chronic wasting syndrome or a fatal immunodeficiency syndrome punctuated by episodes of opportunistic infections and tumors (18). The present studies were performed in the STLV-III/macaque model of AIDS to determine whether any aspects of the humoral immune response to this HTLV-III/ LAV-related retrovirus correlate with clinical outcome of infection.

In this prospective study of six juvenile rhesus monkeys inoculated with STLV-III, two distinct patterns of virus-specific antibody responses were found. The first four animals to die developed low titer anti-STLV-III antibody responses that recognized only the gp 120/160 viral envelope protein. The two that lived longer developed high titer anti-STLV-III antibody responses that recognized both viral envelope and core (p55, p27) proteins. Interestingly, the single animal that has remained clinically healthy was the only one that developed a neutralizing antibody response. While these results suggested a correlation between the nature of the antibody response generated by the STLV-III-infected monkeys and their clinical course, these antiSTLV-III antibody responses in fact also correlated with total plasma IgG levels and the absolute number of peripheral blood T4+ lymphocytes in the monkeys. The four animals that died by $160 \mathrm{~d}$ postinfection showed immediate and progressive declines in total plasma IgG levels and a trend toward a decrease in T4+ PBL postinoculation, while the two animals that survived longer showed significant increases in total plasma IgG and no immediate fall in circulating T4+ PBL. Thus, the nature of the antibody response to STLV-III in the six experimentally infected monkeys reflected an even more general impairment of their immune function.

The present studies indicate a number of parallels between the nature of the antibody responses of the rhesus monkeys to STLV-III and that of humans to HTLV-III/LAV. The four monkeys that died shortly after STLV-III infection developed decreased plasma IgG levels and only low titer-specific antibody responses to the virus, a pattern of humoral response atypical for human AIDS. However, the remaining two STLV-III-infected monkeys developed increased plasma IgG levels and a lymphadenopathy syndrome, just as is seen in humans after HTLV-III/LAV infection (19). While these two animals developed increased plasma IgG levels, suggesting that the regulation of their B cell function was abnormal, they still were capable of generating a high titer STLV-III-specific antibody response. The observation that the two monkeys which had a more chronic disease course were the only inoculated animals that developed antibodies to the core viral antigens is consistent with recent findings in studies of HTLV-III/LAV-infected humans. Those studies suggest that AIDS patients are less likely to have antibodies to the HTLV-III/LAV core antigen than infected individuals with less severe manifestations of disease (20-24).

It is also of note that, as with plasma of HTLV-III/LAVinfected humans, no obvious correlation could be made between the anti-STLV-III antibody titer and antibody-neutralizing capacity of plasma from these two monkeys. Parallel plasma samples from Mm 127-83 and Mm 74-84, while exhibiting differences in detectable anti-core antibody responses but the same anti-STLV-III antibody titers by indirect immunofluorescence, demonstrated differences in neutralizing capacity. A number of phenomena may play a contributing part in this unexpected 
result. The fine specificities of the anti-envelope antibody responses of Mm 127-83 and Mm 74-84 may be quite different,

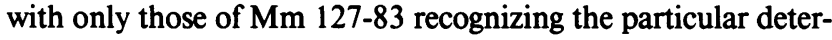
minant(s) of the virus envelope critical for infection of target cells. Moreover, as has been shown in other lentivirus infections, in vivo mutation of the infecting STLV-III virus may occur in these monkeys with a coincident drift in the specificity of the antibody response. Under such conditions, the specificity of the anti-envelope antibodies from these two monkeys for the original infecting virus might be very different. Finally, while little precedent exists for such a phenomenon, the anti-core antibody may be capable of playing a contributing role in blocking STLVIII replication in vitro.

This model provides a unique system for probing these and other questions related to the pathogenesis of AIDS. The study of virus-specific antibody responses in HTLV-III/LAV-infected humans is complicated by a number of important variables. Even in geographically restricted human populations, various HTLV-III/LAV seropositive individuals have been shown to be infected by structurally distinct isolates of the AIDS virus (2528). Moreover, it is usually impossible to determine the precise time of infection of humans. It is also difficult to perform prospective studies that require frequent, invasive interventions. In contrast, in working with the STLV-III/macaque model for AIDS, animals of like age and environmental exposure can be inoculated simultaneously with a single, known viral isolate and studied prospectively with frequent diagnostic interventions. This model should facilitate study of the events in disease pathogenesis that result in the extreme variation in manifestations of AIDS. It should also be useful for vaccine development and anti-viral drug testing for AIDS.

\section{Acknowledgments}

The authors thank Dr. D. Ho, Massachusetts General Hospital, Boston, MA for advice in establishing the neutralization assay; Drs. M. D. Daniel and R. D. Hunt for helpful conversations during the course of these studies; B. Blake for careful reading of this manuscript; B. Roy for preparation of this manuscript; and Dr. P. K. Sehgal for assistance in the care of the experimental animals.

This work was supported by National Institutes of Health grants AI20729, CA38205, CA34949, and CA40680, Division of Research Resources grant RR 00168, and by contracts from the Massachusetts Department of Public Health and grant NO1-CO-23910 from the National Cancer Institute. Dr. Letvin is a recipient of an American Cancer Society Junior Faculty Research Award.

\section{References}

1. Sarngadharan, M. G., M. Popovic, L. Bruch, J. Schupbach, and R. C. Gallo. 1984. Antibodies reactive with human T-lymphotropic retroviruses (HTLV-III) in the serum of patients with AIDS. Science (Wash. DC). 224:506-508.

2. Kalyanaraman, V. S., C. D. Cabradilla, J. P. Getchell, R. Narayanan, E. H. Braff, J. C. Chermann, F. Barre-Sinoussi, L. Montagnier, T. J. Spira, J. Kaplan, D. Fishbein, H. W. Jaffe, J. W. Curran, and D. P. Francis. 1984. Antibodies to the core protein of lymphadenopathyassociated virus (LAV) in patients with AIDS. Science (Wash. DC). 225: 321-323.

3. Weiss, R. A., P. R. Clapham, R. Cheingsong-Popov, A. G. Dalgleish, C. A. Carne, I. V. D. Weller, and R. S. Tedder. 1985. Neutralization of human T-lymphotropic virus type III by sera of AIDS and AIDS-risk patients. Nature (Lond.). 316:69-72.
4. Robert-Guroff, M., M. Brown, and R. C. Gallo. 1985. HTLV-IIIneutralizing antibodies in patients with AIDS and AIDS-related complex. Nature (Lond.). 316:72-74.

5. Alter, H. J., J. W. Eichberg, H. Masur, W. C. Saxinger, R. Gallo, A. M. Macher, H. C. Lane, and A. S. Fauci. 1984. Transmission of HTLV-III infection from human plasma to chimpanzes: an animal model for AIDS. Science (Wash. DC). 226:549-552.

6. Centers for Disease Control. 1984. Experimental infection of chimpanzees with lymphadenopathy-associated virus. $M M W R$. 33:442444.

7. Gajdusek, D. C., H. L. Amyx, C. J. Gibbs, Jr., D. M. Asher, R. T. Yanagihara, P. Rodgers-Johnson, P. W. Brown, P. S. Sarin, R. C. Gallo, Jr., A. Maluish, L. O. Arthur, R. V. Gilden, L. Montagnier, J.-C. Chermann, F. Barre-Sinoussi, D. Mildvan, U. Mathur, and R. Leavitt. 1984. Transmission experiments with human T-lymphotropic retroviruses and human AIDS tissue. Lancet. i:1415-1416.

8. Gajdusek, D. C., H. L. Amyx, C. J. Gibbs, Jr., D. M. Asher, P. Rodgers-Johnson, L. G. Epstein, P. S. Sarin, R. C. Gallo, A. Maluish, L. O. Arthur, L. Montagnier, and D. Mildvan. 1985. Infection of chimpanzees by human T-lymphotropic retroviruses in brain and other tissues from AIDS patients. Lancet. i:55-56.

9. Daniel, M. D., N. L. Letvin, N. W. King, M. Kannagi, P. K. Sehgal, R. D. Hunt, P. J. Kanki, M. Essex, and R. C. Desrosiers. 1985. Isolation of T-cell tropic HTLV-III-like retrovirus from macaques. Science (Wash. DC). 228:1201-1204.

10. Kannagi, M., J. M. Yetz, and N. L. Letvin. 1985. In vitro growth characteristics of simian T-lymphotropic virus type III. Proc. Natl. Acad. Sci. USA. 82:7053-7057.

11. Kanki, P. J., M. F. McLane, N. W. King, Jr., N. L. Letvin, R. D. Hunt, P. Sehgal, M. D. Daniel, R. C. Desrosiers, and M. Essex. 1985. Serologic identification and characterization of a macaque T-lymphotropic retrovirus closely related to HTLV-III. Science (Wash. DC). 228:1199-1201.

12. Letvin, N. L., M. D. Daniel, P. K. Sehgal, R. C. Desrosiers, R. D. Hunt, L. M. Waldron, J. J. MacKey, D. K. Schmidt, L. V. Chalifoux, and N. W. King. 1985. Induction of AIDS-like disease in macaque monkeys with T-cell tropic retrovirus STLV-III. Science (Wash. DC) 230:71-73.

13. McGrath, M., O. Witte, T. Pincus, and I. L. Weissman. 1978. Retrovirus purification: method that conserves envelope glycoprotein and maximizes infectivity. J. Virol. 25:923-927.

14. Laemmli, U. K. 1970. Cleavage of structural proteins during the assembly of the head of bacteriophage T4. Nature (Lond.). 227:680-685.

15. Letvin, N. L., V. S. Goldmacher, J. Ritz, J. M. Yetz, S. F. Schlossman, and J. M. Lambert. 1986. In vivo administration of lymphocyte-specific monoclonal antibodies in nonhuman primates. J. Clin. Invest. 77:977-984.

16. Lane, H. C., H. Masur, E. P. Gelmann, D. L. Longo, R. G. Steis, T. Chused, G. Whalen, L. C. Edgar, and A. S. Fauci. 1985. Correlation between immunologic function and clinical subpopulations of patients with the acquired immune deficiency syndrome. Am. J. Med. 78:417422.

17. Curran, J. W., W. M. Morgan, A. M. Hardy, H. W. Jaffe, W. W. Darrow, and W. R. Dowdle. 1985. The epidemiology of AIDS: current status and future prospects. Science (Wash. DC). 229:1352-1357.

18. Fauci, A. S., H. Masur, E. P. Gelmann, P. D. Markham, B. H. Hahn, and H. C. Lane. 1985. The acquired immunodeficiency syndrome: an update. Ann. Intern. Med. 102:800-813.

19. Lane, H. C., and A. S. Fauci. 1985. Immunologic abnormalities in the acquired immunodeficiency syndrome. Annu. Rev. Immunol. 3: $477-500$.

20. Kalyanaraman, V. S., C. D. Cabradilla, J. P. Getchell, R. Narayanan, E. H. Braff, J.-C. Chermann, F. Barre-Sinoussi, L. Montagnier, T. J. Spira, J. Kaplan, D. Fishbein, H. W. Jaffe, J. W. Curran, and D. P. Francis. 1984. Antibodies to the core protein of lymphadenopathyassociated virus (LAV) in patients with AIDS. Science (Wash. DC). 225: 321-323.

21. Casey, J. M., Y. Kin, P. R. Andersen, K. F. Watson, J. L. Fox, 
and S. G. Devare. 1985. Human T-cell lymphotropic virus type III: immunologic characterization and primary structure analysis of the major internal protein, p24. J. Virol. 55:417-423.

22. Barin, F., M. F. McLane, J. S. Allan, T. H. Lee, J. E. Groopman, and M. Essex. 1985. Virus envelope protein of HTLV-III represents major target antigen for antibodies in AIDS patients. Science (Wash. DC). 228:1094-1096.

23. Steimer, K. S., J. P. Puma, M. D. Power, M. A. Powers, C George-Nascimento, J. C. Stephans, J. A. Levy, R. Sanchez-Pescador, P. A. Luciw, P. J. Barr, and R. A. Hallewell. 1986. Differential antibody responses of individuals infected with AIDS-associated retroviruses surveyed using the viral core antigen p25 expressed in bacteria. Virology. 130:283-290.

24. Rasheed, S., G. L. Norman, P. S. Gill, P. R. Meyer, L Cheng, and A. M. Levine. 1986. Virus-neutralizing activity, serologic heterogeneity, and retrovirus isolation from homosexual men in the Los Angeles area. Virology. 150:1-9.
25. Shaw, G. M., B. H. Hahn, S. K. Arya, J. E. Groopman, R. C. Gallo, and F. Wong-Staal. 1984. Molecular characterization of human T-cell leukemia (lymphotropic) virus type III in the acquired immune deficiency syndrome. Science (Wash. DC). 226:1165-1171.

26. Wong-Staal, F., G. M. Shaw, B. H. Hahn, S. Z. Salahuddin, M. Popovic, P. Markham, R. Redfield, and R. C. Gallo. 1985. Genomic diversity of human T-lymphotropic virus type III (HTLV-III). Science (Wash. DC). 229:759-762.

27. Hahn, B. H., M. A. Gonda, G. M. Shaw, M. Popovic, J. A. Hoxie, R. C. Gallo, and F. Wong-Staal. 1985. Genomic diversity of the acquired immune deficiency syndrome virus HTLV-III: different viruses exhibit greatest divergence in their envelope genes. Proc. Natl. Acad. Sci. USA. 82:4813-4817.

28. Benn, S., R. Rutledge, T. Folks, J. Gold, L. Baker, J. MoCormick, P. Feorino, P. Piot, T. Quinn, and M. Martin. 1985. Genomic heterogeneity of AIDS retroviral isolates from North America and Zaire. Science (Wash. DC). 230:949-951. 